УДК 330.839 : [338.93]

\title{
КОНЦЕПТУАЛЬНІ ЗАСАДИ ІНСТИТУЦІОНАЛЬНОГО ЗАБЕЗПЕЧЕННЯ ЕКОЛОГО-ЕКОНОМІЧНОГО СТАНУ КАРПАТСЬКОГО РЕГІОНУ
}

\author{
А.Я. Гадзало \\ кандидат економі чних наук \\ Інститут агроекології і природокористування \\ Національної академії аграрних наук України \\ (Україна, м. Київ; e-mail: ahadzalo@ukr.net)
}

\begin{abstract}
У статті охарактеризовано сучасний стан соиіалъно-економічних та екологічних показників i особливості розвитку прикордонного Карпатсъкого регіону. Визначено його основні галузі промисловості. Доведено, шо ебективне бункиіонування системи регулювання сталого розвитку Карпатсъкого регіону визначається стратегічними пріоритетами держави, а також програмним підходом до реалізаиії регуляторних дій через систему методів та інструментів, якими володіє держава у здійсненні екологічної політики на транскордонних територіях; виявлені стратегічні пріоритети, що викладені в програмних документах транскордонного співробітництва шуодо розвитку регіонів, здебілъиого мають декларативний характер. Встановлено закономірність розвитку регулювання сталого розвитку Карпатсъкого регіону на засадах екологічної безпеки, шо полягає в посиленні ролі екологічного чинника на прикордонні регіони. Визначено, шо відмінності транскордонних регіонів з обох боків кордону в еколого-економічних аспектах визначають особливості ббукиіонування систем організації, управління та регулювання транскордонного співробітництва на загалънодержавному рівні. Запропоновано кониептуальні ідеї щодо інституиіонального забезпечення збалансованого природокористування, елементи та напрями їх взаємодї. Доведено, шо за допомогою використання економічних важелів досягається збалансоване природокористування та використання стратегічних напрямів реалізаиії інституиіонального забезпечення, оскілъки иі напрями набувають нині актуальності в досліджуваному прикордонному регіоні.
\end{abstract}

Ключові слова: інституиіональне забезпечення, транскордонне співробітництво, прикордонні регіони, еколого-економічні засади, валовий регіональний продукт, капітальні інвестицї, рівень рентабельності.

Постановка проблеми. Нині потенціал регіонального співробітництва України та СС задіяно недостатньо. Так, за участю українських областей єврорегіони (Карпатський, Буг, Верхній Прут та Нижній Дунай), порівняно із іншими аналогічними структурами СС, неповною мірою використовують потенціал транскордонного співробітництва для нівелювання впливу периферійного розміщення на соціально-економічний розвиток прикордонних територій, підвищення конкурентоспроможності ї економік та покращення життєвого рівня мешканців. Крім того, єврорегіональні структури за участю областей України і досі не стали організаційно-фінансовою платформою координації транскордонного співробітництва у системі регіонального менеджменту, що є властиво країнам ЄС $[1 ; 2]$.

Варто зауважити, що в рамках самого ЄC існують значні відмінності в організації соціальної сорери та особливостях надання соціальних послуг. Навіть система вищої освіти у межах Свросоюзу може бути як безкоштовною, так і платною. Певне значення для ринкового механізму має фрунцціонування «Карпатського» єврорегіону, який уже понад 20 років продовжує відігравати роль організатора і координатора міжрегіонального та транскордонного співробітництва у найрізноманітніших сорерах економічного й суспільного життя. Зокрема, саме через інституції «Карпатського» єврорегіону Закарпатська обл. встановила партнерські зв'язки з низкою регіонів Угорщини, Словаччини, Румунії та Польщі. 3 деякими із цих регіонів розробляються і реалізуються конкретні програми співпраці [3].

Аналіз останніх досліджень і публікацій. Напрям інституціонального забезпечення економічного розвитку - це актуальна тематика, оскільки сорера еколого-економічних взаємовідносин є гуманітарною і найбільшою мірою залежить від чинників інституціонального характеру. Класичні аспекти фрормування інституціонального забезпечення для суб'єктів економічної діяльності визначено в роботах багатьох вчених, як-от: Т. Веблен, Дж. Коммонс, Р. Коуз, Д. Норт, Ф. Фукуяма, які розкривають сутність впливу нормативно-правових, недормальних, гуманітарних чинників на екологоекономічний розвиток. Вітчизняні вчені, які 
досліджували теоретико-методичні аспекти еколого-економічних та інституціональних механізмів, що спрямовані на удосконалення концепції сталого розвитку, висвітлено в наукових працях Л.Г. Мельника, З.В. Герасимчук, О.І. Дребот, Н.В. Зіновчук, В.В. Химинця. Їх наукові праці послужили теоретико-методологічною базою дослідження і надали змогу виявити низку проблем щодо інституціонального забезпечення збалансованого природокористування.

Виділення невирішених раніше частин загальної проблеми. На сьогодні не визначено науково-методичного підходу до екологоекономічного та інституціонального механізму щодо визначення та реалізації концепції сталого розвитку на регіональному рівні.

Метою дослідження є визначення концептуальних засад та сприяння інституціонального забезпечення еколого-економічного стану Карпатського регіону.

Матеріали та методи. Теоретико-методологічною основою дослідження є методи та підходи інституціональної теорії, а також теорії мотивації щодо сталого еколого-економічного розвитку Карпатського регіону транскордонних регіонів, зокрема: системний, просторовий та синергетичний підходи, метод аналізу та синтезу, аналітичний, абстрактно-логічний та експериментальний методи. Інформаційну базу дослідження становлять вітчизняні та міжнародні нормативно-правові акти у сорері транскордонного співробітництва, матеріали і звіти Державної служби статистки України, Міністерства економічного розвитку і торгівлі України, а також методичні рекомендації наукових установ, інорормація з мережі Інтернет, матеріали власних досліджень, інші літературні джерела з проблематики дослідження.

Виклад основного матеріалу дослідження. Розвиток транскордонного співробітництва (ТC) визначається як один із сучасних ефективних напрямів реалізації екологічної політики держави. Чіткий механізм транскордонного співробітництва є необхідною передумовою його дієвості та результативності. Карпатський регіон став важливим інструментом співробітництва місцевих і регіональних влад України не лише з окремими державами, але й Свросоюзом загалом [4; 5]. У Карпатський регіон входить чотири області - це Львівська, Івано-Франківська, Закарпатська та Чернівецька. Карпатський регіон налічує близько 56,7 тис. км² 9,4\% території України; населення — майже 6,4 млн осіб, або $12 \%$ населення України. Головною метою створення в 1993 р. Карпатського регіону було налагодження добросусідських відносин, забезпечення соціальної стабільності, сприяння еколого-економічному розвитку на прикордонних територіях країн-членів, співробітництво з національними інституціями та організаціями тощо [6].

Основними видами співпраці в Карпатському регіоні є: туризм та рекреація $(74,6 \%)$, розвиток транспорту $(60,7)$, культурна співпраця $(67,0 \%)$ [7]. Зауважимо, що на щільність розміщення населення значною мірою впливають екологічні та економічні чинники, але не менш важливим є вплив площ територій. У підсумку, кількість населення в областях Карпатського регіону є неоднаковою (табл. 1). У більшості областей сільське населення переважає міське, зокрема в Івано-Франківській, Закарпатській, Чернівецькій, - щільність населення яких наближається до європейського рівня.

Середньомісячна заробітна плата в областях Карпатського регіону є нижчою, ніж у середньому в Україні. Найвищий рівень середньомісячної заробітної плати у 2017 р. був у Львівській обл. - 6391 грн, або 206,4 євро, найнижчий - у Чернівецькій обл. - 5621 грн, або 744,1 євро (табл. 2). У країнах Карпатського регіону частка заробітної плати варіювала у межах 66-87\%, зокрема: у Румунії, Польщі — 77\%, Угорщині, Словаччині — $74 \%$ [8]. У середньому оплата години праці в Україні становила 1,1 євро, у країнах СС - 28-25 євро. У країнах Карпатського єврорегіону цей показник є нижчим: у Словаччині - 10 євро, Польщі - 8,6, Угорщині - 7,5, Румунії - 5 євро. Для порівняння: у Данії - 41,3 євро, Швеції - 37,4, Франції - 35,1, Німеччині — 32,2 євро [8].

Рівень соціально-економічного розвитку Карпатського регіону визначається як середній: за величиною валового регіонального продукту у розрахунку на одну особу (грн), Львівська обл. є лідером, і цей показник становить 48345 грн, а Чернівецька обл. має найнижчі показники в Україні — 26347 грн. Рівень рентабельності (сільського та лісового господарства) має найвищі показники - 19,7\%, найнижчі показники в Івано-Франківській обл. - 10,8\%. Щодо капітальних інвестицій, Закарпатська обл. має найвищі в Карпатському регіоні показники, найнижчі - Чернівецька обл. (табл. 3).

Покращення економічних показників відбувається завдяки розвитку малого та середнього бізнесу, надходження інвестицій, поліпшення умов проживання, забезпечення добробуту населення. Основним чинником, що сприятиме зростанню показника валового регіонального продукту (ВРП) у Карпатському регіоні, є інвестиції. Як демонструє динаміка інвестицій упродовж 2013-2017 рр., капітальні інвестиції збільшилися на 14,4\% загалом у регіоні. Тенденція надходження інвестицій 
Територія і кількість наявного населення Карпатського регіону станом на 2017 р.

\begin{tabular}{|c|c|c|c|c|c|}
\hline \multirow{2}{*}{ Область } & \multirow{2}{*}{$\begin{array}{l}\text { Територія, } \\
\text { тис. км }\end{array}$} & \multirow{2}{*}{$\begin{array}{c}\text { Кількість } \\
\text { населення, } \\
\text { тис. осіб }\end{array}$} & \multicolumn{2}{|c|}{ У тому числі } & \multirow{2}{*}{$\begin{array}{c}\text { Щільність } \\
\text { населення на } \\
1 \text { км², осіб }\end{array}$} \\
\hline & & & міське & сільське & \\
\hline Україна & 603,5 & 42386,4 & 29371,0 & 13015,4 & 69,2 \\
\hline Карпатський регіон & 56,607 & 6071,9 & 3004,3 & 3067,6 & 404 \\
\hline Львівська & 21,831 & 2529,6 & 1542,1 & 987,5 & 112,2 \\
\hline Івано-Франківська & 13,927 & 1377,5 & 606,2 & 771,3 & 92,2 \\
\hline Закарпатська & 12,753 & 1258,1 & 465,5 & 792,6 & 92,3 \\
\hline Чернівецька & 8,096 & 906,7 & 390,5 & 516,2 & 107,3 \\
\hline Польща & 312679 & 35800 & 28500 & 7300 & 120,9 \\
\hline $\begin{array}{l}\text { Підкарпатське } \\
\text { воєводство }\end{array}$ & 17,845 & 2128 & 1448 & 680 & 118 \\
\hline Словаччина & 49,036 & 5825 & 3452 & 2373 & 111 \\
\hline Кошицький край & 6,756 & 825 & 487 & 338 & 82 \\
\hline Пряшівський край & 9,12 & 845 & 521 & 324 & 91 \\
\hline
\end{tabular}

Джерело: сорормовано за даними статистики України, Польщі, Словаччини.

Таблиияя 2

Середньомісячна заробітна плата в областях Карпатського регіону, за 2013-2017 рр., грн

\begin{tabular}{|l|c|c|c|c|c|}
\hline \multicolumn{1}{|c|}{ Область } & $\mathbf{2 0 1 3}$ & $\mathbf{2 0 1 4}$ & $\mathbf{2 0 1 5}$ & $\mathbf{2 0 1 6}$ & $\mathbf{2 0 1 7}$ \\
\hline \hline Львівська & 2789 & 2961 & 3646 & 4559 & 6391 \\
\hline Івано-Франківська & 2679 & 2875 & 3402 & 4202 & 6074 \\
\hline Закарпатська & 2553 & 2744 & 3381 & 4298 & 6355 \\
\hline Чернівецька & 2484 & 2578 & 3050 & 3828 & 5621 \\
\hline Україна & 3265 & 3480 & 4195 & 5183 & 7104 \\
\hline Карпатський регіон & $\mathbf{1 0 5 0 5}$ & $\mathbf{1 1 ~ 1 5 8}$ & $\mathbf{1 3 4 7 9}$ & $\mathbf{1 6 ~ 8 8 7}$ & $\mathbf{2 4} \mathbf{4 4 1}$ \\
\hline
\end{tabular}

Джерело: сформовано за даними Державної служби статистики України.

Таблиия 3

Соціально-економічні показники розвитку Карпатського регіону, за 2013-2017 рp.

\begin{tabular}{|l|c|c|c|c|c|}
\hline \multicolumn{1}{|c|}{ Область } & $\mathbf{2 0 1 3}$ & $\mathbf{2 0 1 4}$ & $\mathbf{2 0 1 5}$ & $\mathbf{2 0 1 6}$ & $\mathbf{2 0 1 7}$ \\
\hline \hline \multicolumn{2}{|c|}{ Валовий регіональний продукт $y$ розрахунку на одну особу, грн } \\
\hline Львівська & 24937 & 28731 & 37338 & 45319 & 48345 \\
\hline $\begin{array}{l}\text { Івано- } \\
\text { Франківська }\end{array}$ & 24022 & 27232 & 33170 & 37220 & 39342 \\
\hline Закарпатська & 17044 & 19170 & 22989 & 25727 & 27654 \\
\hline Чернівецька & 15154 & 16552 & 20338 & 2336 & 26347 \\
\hline Україна & 33473 & 36904 & 46413 & 55899 & 58321 \\
\hline $\begin{array}{l}\text { Карпатський } \\
\text { регіон }\end{array}$ & $\mathbf{8 1 1 5 7}$ & $\mathbf{9 1 6 8 5}$ & $\mathbf{1 1 3 8 3 5}$ & $\mathbf{1 3 1 6 3 1}$ & $\mathbf{1 4 1 6 8 8}$ \\
\hline
\end{tabular}




\begin{tabular}{|c|c|c|c|c|c|}
\hline Область & 2013 & 2014 & 2015 & 2016 & 2017 \\
\hline \multicolumn{6}{|c|}{ Валовий регіональний продукт, млн грн } \\
\hline Львівська & 63329 & 72923 & 94690 & 114842 & 135321 \\
\hline $\begin{array}{l}\text { Івано- } \\
\text { Франківська }\end{array}$ & 33196 & 37643 & 45854 & 51404 & 53541 \\
\hline Закарпатська & 21400 & 24120 & 28952 & 32390 & 34213 \\
\hline Чернівецька & 13757 & 15049 & 18506 & 21239 & 23421 \\
\hline Україна & 1522657 & 1586915 & 1988544 & 2385367 & 2567844 \\
\hline $\begin{array}{l}\text { Карпатський } \\
\text { регіон }\end{array}$ & 131682 & 149735 & 188002 & 219875 & 246496 \\
\hline \multicolumn{6}{|c|}{ Рівенъ рентабельності (сілъсъкого та лісового господарства), \% } \\
\hline Львівська & 11,8 & 9,6 & 11,8 & 20,3 & 15,7 \\
\hline $\begin{array}{l}\text { Івано- } \\
\text { Франківська }\end{array}$ & 9,8 & 12,9 & 18,6 & 8,6 & 10,8 \\
\hline Закарпатська & 12,5 & 15,8 & 19,5 & 16,5 & 19,7 \\
\hline Чернівецька & 18,3 & 20,3 & 24,3 & 11,6 & $-16,1$ \\
\hline Україна & 30,5 & 37,2 & 41,7 & 32,4 & 22,4 \\
\hline $\begin{array}{l}\text { Карпатський } \\
\text { регіон }\end{array}$ & 52,4 & 58,6 & 74,2 & 57 & 30,1 \\
\hline \multicolumn{6}{|c|}{ Капітальні інвестищї̈, \% } \\
\hline Львівська & 81,4 & 88,5 & 106,5 & 130,7 & 126,0 \\
\hline $\begin{array}{l}\text { Івано- } \\
\text { Франківська }\end{array}$ & 87,6 & 126,9 & 110,2 & 65,3 & 132,1 \\
\hline Закарпатська & 87,1 & 94,6 & 114,1 & 93,9 & 132,4 \\
\hline Чернівецька & 96,4 & 63,9 & 132,4 & 85,9 & 106,4 \\
\hline Україна & 88,9 & 75,9 & 98,3 & 118,0 & 122,1 \\
\hline $\begin{array}{l}\text { Карпатський } \\
\text { регіон }\end{array}$ & 352,5 & 373,9 & 463,3 & 375,8 & 496,9 \\
\hline
\end{tabular}

Джерело: сформовано за даними Державної служби статистики України.

свідчить, що впродовж останніх років державне регулювання приділяє мало уваги залученню інвестицій у регіон, не сприяє розвитку науково-технічного потенціалу, відповідно, все це впливає на погіршення показника ВРП Карпатського регіону. Основним розвитком Карпатського регіону повинна бути соціальна спрямованість, що передбачатиме дотримання економічної та екологічної рівноваги навколишнього природного середовища. У Карпатському регіоні, як і в більшості областей України, спостерігається значний рівень безробіття. Ця проблема особливо стосується сільської місцевості. 3 наведених вище соціально-економічних показників можна зробити висновок, що розвиток Карпатського регіону сповільнюють чинники, як-от: критичний демографічний стан, збільшення господарських взаємозв'язків, частки безробітного населення, розбалансованість. Невтішною є статистика і щодо міграції, за межі України виїздить велика частина працездатного населення у пошуку роботи.

Основні галузі промисловості областей Карпатського регіону мають майже однакову тенденцію використання у відсотковому значенні. Розглянемо структуру промислового комплексу Карпатського регіону: у Львівській обл. переважає деревообробна, легка, хімічна, нафртовидобувна, харчова галузі промисловості, Закарпатська, Івано-Франківська, Чернівецька області мають схожі спеціалізації, основу яких становить лісопромисловий комплекс. 
Економічно обгрунтованим і перспективним для регіону є розвиток народних промислів - вишивання, виготовлення художніх виробів 3 лози, дерева, різьблення на дереві, гончарство, адже цей напрям промисловості створює умови для зайнятості населення та отримання доходу, в основному, у гірських та передгірських регіонах (рис. 1).

Для Карпатського регіону характерними є економічні, соціальні та екологічні особливості. Найбільший тиск на навколишнє природнє середовище в регіоні спричиняють [9; 10]:

- автотранспортна і залізнична галузі;

- сільськогосподарське виробництво; лів;

• потужні джерела електромагнітних по-

- нехтування наукового обгрунтовання вирубки лісів, що супроводжується виникненням низки проблем (ерозія, руйнування родючості шару грунту).

Важливими складовими екологічних проблем Карпатського регіону є: неналежне ставлення до використання природних ресурсів, незбалансованість розвитку певних сорер економіки та промисловості, усі ці чинники призводять до нераціонального природокористування і погіршення довкілля. Карпатський регіон, на відміну від інших регіонів України (таких як Донбас, Придніпров'я), не має поширеного забруднення загального площинного характеру. Але в деяких місцях сорормувалися стійкі вогнища загрозливого екологічного стану (наприклад, у межах Дрогобицької агломерації -
Дрогобич, Борислав, Стебник, Трускавець, де потужні гірничо-хімічна, нафтопереробна, лакофарбова та інші галузі промисловості становлять загрозу розвитку рекреаційного господарства; аналогічна ситуація склалася і в межах Львівсько-Волинського вугільного басейну, зокрема в зонах впливу Яворівського і Роздільського ВО «Сірка», Калуського ВО «Оріана») [11; 12]. Не менш загрозливими також $€$ й інші чинники, як-от: екологічна незбалансованість структури сільгоспугідь, ігнорування екологічної місткості та ерозійної стійкості ландшафртів, надмірна розораність території, нераціональне ведення лісового господарства без урахування екологічних функцій лісів.

У земельному фонді Карпатського регіону станом на 01.01.2018 р. домінують сільськогосподарські землі (2 811,7 тис. га), ліси та інші лісовкриті площі (2 304,1), забудовані землі $(344,8)$, землі під водою $(103,6)$, відкриті заболочені землі (37,2 тис. га) (табл. 4).

Наведена характеристика земельного фонду Карпатського регіону переконливо засвідчує, що в його межах домінують сільськогосподарське та лісогосподарське землекористування, яке доповнюється природоохоронним і рекреаційним потенціалом.

Оцінка екологічного стану земельних угідь у Карпатському регіоні за розрахунками коефіцієнта розораності становить 2,25 , оскільки рівень розораності земель України є найвищим у світі і становить понад $51,2 \%$ сільськогосподарських угідь, коефіцієнт екологічної

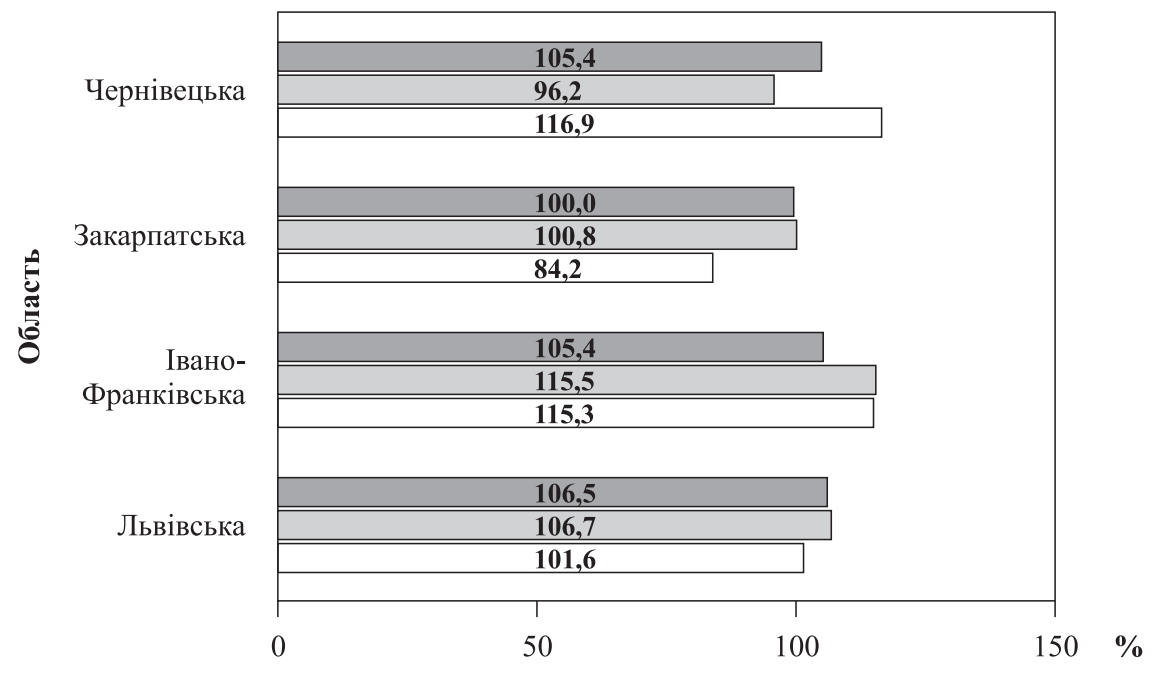

$\square$ Постачання електроенергії, газу, пари та кондиційованого повітря
$\square$ Переробна промисловість
$\square$ Добувна промисловість

Рис. 1. Основні галузі промисловості Карпатсъкого регіону, за 2017 p.

Джерело: сформовано за даними Державної служби статистики України. 
Структура земельного фонду Карпатського регіону, тис. га

\begin{tabular}{|l|c|c|c|c|c|c|}
\hline \multicolumn{1}{|c|}{ Область } & $\begin{array}{c}\text { Усього } \\
\text { земель }\end{array}$ & С.-г. угіддя & $\begin{array}{c}\text { Ліси та інші } \\
\text { лісовкриті } \\
\text { площі }\end{array}$ & $\begin{array}{c}\text { Забудовані } \\
\text { землі }\end{array}$ & $\begin{array}{c}\text { Землі під } \\
\text { водою }\end{array}$ & $\begin{array}{c}\text { Відкриті } \\
\text { заболочені } \\
\text { землі }\end{array}$ \\
\hline \hline Львівська & 2183,1 & 1260,8 & 694,7 & 144,4 & 42,8 & 32,5 \\
\hline $\begin{array}{l}\text { Івано- } \\
\text { Франківська }\end{array}$ & 1392,7 & 629,9 & 635,9 & 77,5 & 23,8 & 2,6 \\
\hline Закарпатська & 1275,3 & 451,3 & 723,6 & 63,3 & 18,2 & 0,9 \\
\hline Чернівецька & 809,6 & 469,7 & 249,9 & 59,6 & 18,8 & 1,2 \\
\hline Україна & 60354,9 & 41489,3 & 10674,9 & 3597,8 & 2425,0 & 1089,4 \\
\hline $\begin{array}{l}\text { Карпатський } \\
\text { регіон }\end{array}$ & $\mathbf{5 6 6 0 , 7}$ & $\mathbf{2 8 1 1 , 7}$ & $\mathbf{2 3 0 4 , 1}$ & $\mathbf{3 4 4 , 8}$ & $\mathbf{1 0 3 , 6}$ & $\mathbf{3 7 , 2}$ \\
\hline
\end{tabular}

Джерело: сформовано за даними Державної служби статистики України.

стабільності в середньому варіює у межах 0,55 (середньостабільний) - 0,58 (стабільний). Високу забрудненість грунтів регіону мінеральними добривами і пестицидами значною мірою спричинено галузевою спеціалізацією сільського господарства. Площа забруднених сільськогосподарських угідь у Карпатському регіоні становить 27,6 тис. га (Івано-Франківська і Чернівецька області). Проведені розрахунки дають можливість екологічно оцінити збалансований рівень земельних угідь (табл. 5).

У деяких прикарпатських областях сорормувалися стабільні території із значним (або критичним) рівнем загрозливого екологічного стану. Останніми роками значно зросла загроза виникнення екологічно небезпечних техногенних аварій і катастрофр. За забрудненістю повітря і вод Карпатський регіон, за даними
В. Гобели $[13 ; 14]$, займає четверте, а за забрудненістю грунтів мінеральними добривами і пестицидами — відповідно перше і друге місця в Україні.

Водні ресурси використовуються вкрай нераціонально, неекономно і, крім того, відбувається значне їх забруднення як промисловими, так і сільськогосподарськими стоками та відходами. Найбільшими забруднювачами поверхневих та підземних вод є населені пункти, оскільки в них, як правило, відсутні очисні споруди та каналізація. Карпатський регіон залишається найнебезпечнішим з огляду на такі природні катаклізми, як паводки. Загроза паводків найближчими роками має тенденцію до збільшення. Щороку внаслідок затоплень потерпають всі області Карпатського регіону. Тому основним запобіжником цим процесам

Таблиияя 5

Оцінка екологічного стану земельних угідь Карпатського регіону станом на 01.01.2018 р.

\begin{tabular}{|l|c|c|c|c|c|c|}
\hline \multicolumn{1}{|c|}{ Область } & $\begin{array}{c}\text { С.-г. угіддя, } \\
\text { тис. га }\end{array}$ & $\begin{array}{c}\text { Рілля, } \\
\text { тис. га }\end{array}$ & $\begin{array}{c}\text { Загальна площа } \\
\text { екологічної } \\
\text { мережі, тис. га }\end{array}$ & $\begin{array}{c}\text { Площа } \\
\text { Коеріцієнт } \\
\text { розораності }\end{array}$ & $\begin{array}{c}\text { кабруднених } \\
\text { с.-г. угідь, } \\
\text { тис. га }\end{array}$ & $\begin{array}{c}\text { екологічної } \\
\text { стабільності }\end{array}$ \\
\hline \hline Львівська & 1260,8 & 793,4 & 148,6 & 0,64 & 9 & 0,55 \\
\hline $\begin{array}{l}\text { Івано- } \\
\text { Франківська }\end{array}$ & 629,9 & 397,1 & 947,4 & 0,51 & - & 0,60 \\
\hline Закарпатська & 451,3 & 200,4 & 983,1 & 0,42 & 0,74 \\
\hline Чернівецька & 469,7 & 330,8 & 103,6 & 0,68 & 18,6 & 0,52 \\
\hline Україна & 41489,3 & 32544,3 & 18767,3 & 0,74 & 463,9 & 0,52 \\
\hline $\begin{array}{l}\text { Карпатський } \\
\text { регіон }\end{array}$ & $\mathbf{2 8 1 1 , 7}$ & $\mathbf{1 7 2 1 , 7}$ & $\mathbf{2 1 8 2 , 7}$ & $\mathbf{2 , 2 5}$ & $\mathbf{2 7 , 6}$ & $\mathbf{0 , 5 8}$ \\
\hline
\end{tabular}

Джерело: сформовано за даними Державної служби статистики України і Міністерства екології та природних ресурсів України. 
є створення безпечних умов фрункціонування вказаного регіону, а саме: проведення протипаводкових робіт для утримання грунтів, укріплення дамб та інших захисних споруд.

Важливою проблемою Карпатського регіону, що у перспективі може гальмувати розвиток його рекреаційної сорери, є несприятлива екологічна ситуація, зумовлена багатьма чинниками, як-от: незбалансованість розвитку деяких галузей економіки і промисловості, неналежне ставлення до природних ресурсів та довкілля тощо. На думку фрахівців, усе це призвело до інтенсивного, нераціонального природокористування, погіршення навколишнього природного середовища загалом. Забрудненість середовища безпосередньо залежить від дії забруднювальних джерел та чинників, які негативно впливають на здоров'я населення, показники смертності та дитячої захворюваності [14].

Екологічна ситуація свідчить, що для більшої частини Карпатського регіону характерними є значна забрудненість навколишнього природного середовища. У цьому аспекті актуальними є відповідна теоретико-методологічна розробка та належна практична реалізація транскордонного еколого-економічного співробітництва Карпатського регіону, що уможливлять здійснення збалансованого природокористування через створення цілісного еколого-економічного механізму та інституціонального забезпечення. Ключовою сорерою транскордонного співробітництва сусідніх країн є питання щодо охорони навколишнього природного середовища на прикордонних територіях, оскільки саме вони створюють необхідні умови для нормального існування розвитку суспільства. Непроста екологічна ситуація, актуальність проблем раціонального природокористування потребують обов' язкових зусиль всіх його учасників з обох боків кордону. Про стан екологічної ситуації у прикордонних регіонах сусідніх країн свідчать дані стосовно чистоти повітря, обсягу забруднення грунтів, витрат на охорону навколишнього природнього середовища, адресних інвестицій з боку місцевих і регіональних влад прикордонних територій (табл. 6).

Екологічний показник викидів забруднювальних речовин у атмосорерне повітря є найвищим у прикордонному регіоні Івано-Франківської обл. (Україна) - у 2017 р. він становив 198,3 тис. т, у транскордонному регіоні Кошицького краю (Словаччина) у 2017 р. - 146,3 тис. т. Стаціонарні джерела забруднення в Польщі сконцентровано в поясі «Пулави — Люблін Богданка - Рейовець-Фабричний - Холм». Обтяжливі для довкілля джерела емісії роз- міщуються і у деяких інших польських містах, як-от: Замостя, Красник, Біла-Підляська і Радзинь-Підляський. У Підкарпатському воєводстві можна виділити три пояси зі стаціонарними джерелами забруднення повітря: Дембиця Ропчице - Ряшів - Ланьцут - Пшеворськ; Мелець - Тарнобжег - Стальова - Воля; Ясло - Коросно - Сянок, а також кілька точкових джерел: Ніско, Лежонськ і Пшемисль [15].

Проблеми транскордонних забруднень природних ресурсів та нераціонального природокористування - одні із найбільш нагальних і гострих проблем сучасності, розв'язання яких потребує участі всіх держав як на національному, так і на транснаціональному рівнях, особливо держав-сусідів. Науковці справедливо стверджують, що екологічні проблеми не обмежуються національними кордонами, вони мають загальнопланетарний характер. Взаємозв'язок екологічних проблем ТС з економічними та соціальними свідчить про необхідність рівноцінного врахування кожного чинника у розробці відповідних програм. Зважаючи на те, що європейський вектор зовнішньої політики України, зокрема співробітництво та вступ до Європейського Союзу є пріоритетним, в Україні наразі необхідно розробити таку теоретикометодологічну основу й відповідні практичні заходи, які зможуть забезпечити позитивні зрушення розвитку України в напрямі євроінтеграції. Саме тому особливо важливими й актуальними аспектами в цьому напрямі є відповідна теоретико-методологічна розробка і належна практична реалізація транскордонного еколого-економічного співробітництва Карпатського регіону, що відповідатимуть вимогам ЄС. Вивчення еколого-економічних чинників у прикордонних регіонах України та сусідніх держав ЄC набирає особливого значення, оскільки європейський вектор зовнішньої політики України, зокрема співробітництво та вступ до ЄС, є пріоритетними.

Можна дійти висновку, що нині населення Карпатського регіону проживає в умовах соціально-економічного дискомфорту, зі значними екологічними, економічними та соціальними проблемами, розв'язання яких потребує зусиль як з боку держави, так і громадськості. Визначальними у розв'язанні існуючих між людською діяльністю та природою протиріч мають стати всі методи і засоби, з допомогою яких можна фрормувати екологічну культуру та екологічну свідомість населення [16].

Суть фрунцціонування інституціонального забезпечення у напрямі природокористування полягає у розробці законів, норм і правил формування парадигми збалансованого природокористування. Передусім, потрібно здій- 
Екологічні показники транскордонних регіонів

\begin{tabular}{|c|c|c|c|c|c|c|c|}
\hline \multirow[b]{2}{*}{ Національні регіони } & \multicolumn{7}{|c|}{ Викиди забруднювальних речовин у атмосферне повітря за роками, тис. т } \\
\hline & 2005 & 2010 & 2013 & 2015 & 2016 & 2017 & $\begin{array}{c}2017 \mathrm{p} . \\
\text { до } 2005 \text { p. }\end{array}$ \\
\hline $\begin{array}{l}\text { Закарпатська область } \\
\text { України }\end{array}$ & 65,9 & 87,3 & 69,2 & 60,5 & 55,8 & 50,7 & 15,2 \\
\hline $\begin{array}{l}\text { Львівська область } \\
\text { України }\end{array}$ & 187,6 & 246,3 & 238,4 & 209,6 & 189,3 & 178,0 & 9,6 \\
\hline $\begin{array}{l}\text { Івано-Франківська } \\
\text { область Україна }\end{array}$ & 196,4 & 169,2 & 202,9 & 223,9 & 196,7 & 198,3 & 1,9 \\
\hline $\begin{array}{l}\text { Чернівецька область } \\
\text { Україна }\end{array}$ & 45,9 & 39,8 & 20,7 & 3,2 & 30,0 & 33,4 & 12,5 \\
\hline $\begin{array}{l}\text { Підкарпатське } \\
\text { воєводство Польщі }\end{array}$ & 30,6 & 23,1 & 19,8 & 17,8 & 16,9 & 15,5 & 15,1 \\
\hline $\begin{array}{l}\text { Кошицький край } \\
\text { Словаччини }\end{array}$ & 170,2 & 127,8 & 134,1 & 144,2 & 150,5 & 146,3 & 23,9 \\
\hline $\begin{array}{l}\text { Пряшівський край } \\
\text { Словаччини }\end{array}$ & 21,4 & 16,4 & 16,4 & 18,9 & 18,9 & 20,2 & 1,2 \\
\hline \multirow[b]{2}{*}{ Національні регіони } & \multicolumn{7}{|c|}{ Скиди забруднених стічних вод за роками, млн м ${ }^{3}$} \\
\hline & 2005 & 2010 & 2013 & 2015 & 2016 & 2017 & $\begin{array}{c}2017 \mathrm{p} . \\
\text { до } 2005 \mathrm{p} .\end{array}$ \\
\hline $\begin{array}{l}\text { Закарпатська область } \\
\text { України }\end{array}$ & 13,0 & 7,8 & 2,4 & 2,1 & 1,9 & 1,5 & 11,5 \\
\hline $\begin{array}{l}\text { Львівська область } \\
\text { України }\end{array}$ & 193,3 & 59,3 & 43,5 & 39,4 & 34,4 & 29,2 & 164,1 \\
\hline $\begin{array}{l}\text { Івано-Франківська } \\
\text { область Україна }\end{array}$ & 25,5 & 15,5 & 2,4 & 1,9 & 1,5 & 1,4 & 24,1 \\
\hline $\begin{array}{l}\text { Чернівецька область } \\
\text { Україна }\end{array}$ & 13,4 & 7,6 & 3,5 & 2,3 & 2,1 & 1,9 & 11,5 \\
\hline $\begin{array}{l}\text { Підкарпатське } \\
\text { воєводство Польщі }\end{array}$ & 5,3 & 1,0 & 1,3 & 1,5 & 1,4 & 1.2 & 0,2 \\
\hline $\begin{array}{l}\text { Кошицький край } \\
\text { Словаччини }\end{array}$ & 12,5 & 1,0 & 1,9 & 10,5 & 8,5 & 6,8 & 5,8 \\
\hline $\begin{array}{l}\text { Пряшівський край } \\
\text { Словаччини }\end{array}$ & 2,5 & 0,7 & 0,4 & 0,9 & 0,7 & 0,8 & 1,7 \\
\hline
\end{tabular}

Джерело: сформовано за даними статистики України, Польщі, Словаччини.

снити інвентаризацію чинного законодавства, що забезпечить: виявлення правових норм, які підлягають скасуванню чи перегляду; усунення розбіжностей і суперечностей між окремими нормативно-правовими актами. Варто зауважити, що в жодному із наведених нормативноправових актів немає чіткого роз'яснення та опису механізму здійснення ТС та оцінки його еколого-економічної ефективності, що є важливим у дотриманні фрорми зовнішньоекономічної співпраці. В угодах та проектах чітко мають бути окреслені такі положення: назва, сутність і мета здійснення певної форми ТС, термін її реалізації, відповідність пріоритетним напрямам транскордонного розвитку регіонів-учасників та країн-учасниць із переліком відповідних угод та нормативно-правових актів, прийнятих урядами і місцевими органами управління сторін, учасники (їх кількість і територіальна належність), обгрунтування необхідності реалізації форми ТС, її фрінансове забезпечення, організаційна структура, керівництво, його повноваження та обов'язки, вирішення спірних питань, план впровадження проекту, правове забезпечення, очікуваний ефект (соціальний, економічний, екологічний, гуманітарний тощо) та соціо-еколого-економічні показники ефективності (за якими можна дійти висновку щодо 
ступеня досягнення очікуваного збалансованого результату). На рис. 2 наведено концептуальні ідеї щодо інституціонального забезпечення збалансованого природокористування, елементи та напрями їх взаємодії.

Але якщо детально розглянути кожну складову структури цього механізму, то починати треба з інфрормаційної складової, зокрема: інорормації щодо моніторингу довкілля та навколишнього природного середовища з обох боків кордону, оцінки доцільної інвестиційної діяльності, інорормації про стан використання природних ресурсів, інформації щодо виконання завдань, принципів, які прописані у програмних угодах транскордонного та прикордонного співробітництва тощо.
Оскільки інформація, яка надходить від різних сорер діяльності, змінює характер і стан певного регіону, можна спрогнозувати економічний, екологічний та соціальний його стан. Iснує певна особливість щодо удосконалення нормативно-правового забезпечення. У цьому разі нормативно-правові акти відіграють важливу роль у здійсненні контролю за дією економічних інструментів та важелів. Так, інституціональне забезпечення збалансованого природокористування є запорукою еколого-економічного механізму на прикордонні та транскордонні регіони незалежно від організаційно-правових форм суб'єктів господарювання.

Висновки. Забезпечуючи фрунцції екологічного управління щодо встановлення еко-

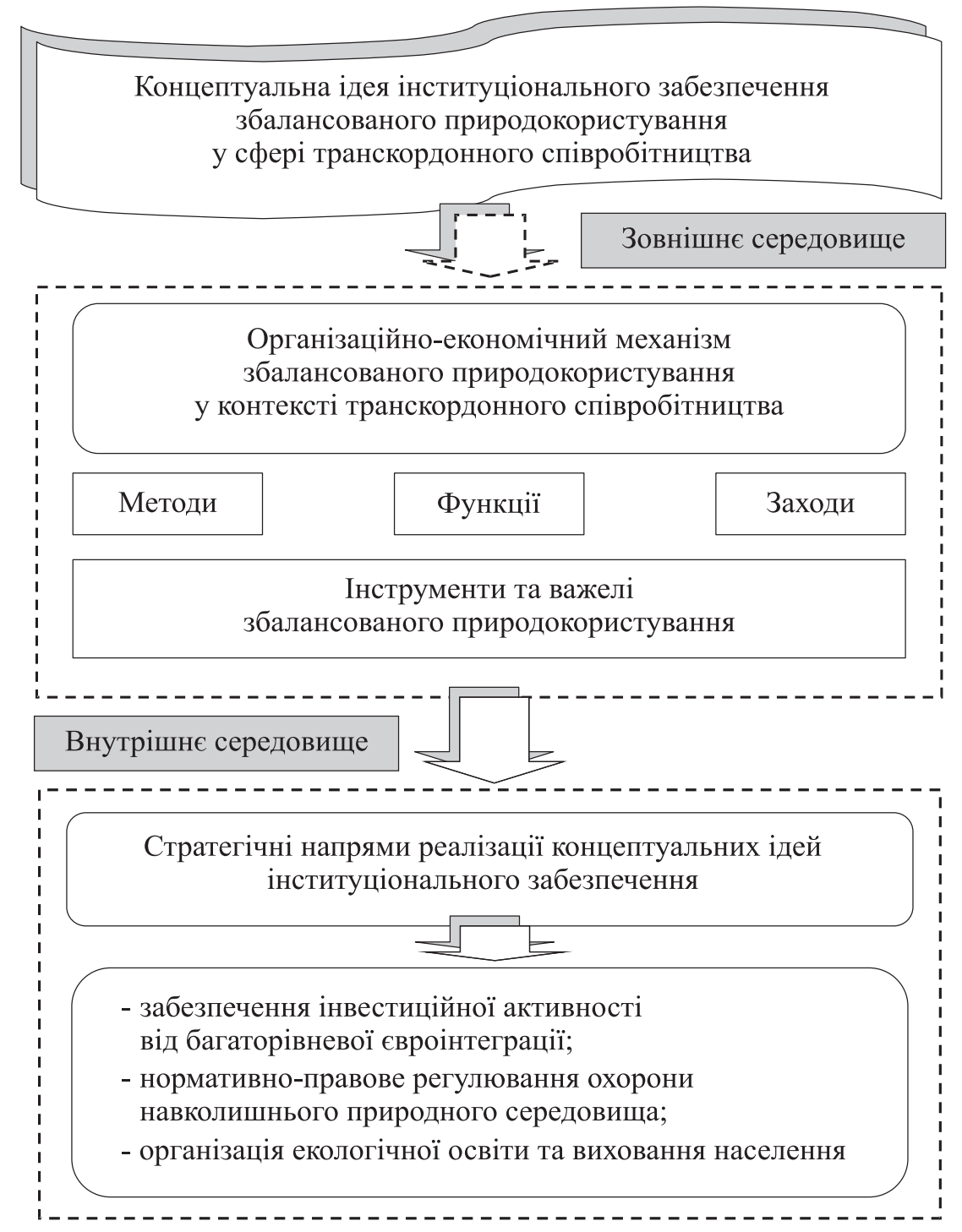

Рис. 2. Концептуалъна схема інституціонального забезпечення збалансованого природокористування у контексті транскордонного співробітництва Джерело: розроблено автором. 
логічних нормативів і контролю за їх використанням, можна простежити стан навколишнього природного середовища. На сьогодні вагомим стримувальним чинником $є$ те, що на прикордонні регіони не поширюються неформальні інституціональні норми і правила щодо їх збалансованого природокористування. До нормативно-правового регулювання навколишнього природнього середовища входить застосування економічних методів та важелів, як-от: залучення інвестицій у прикордонні регіони України, фрінансове забезпечення програм транскордонного співробітництва, екологічний податок, спеціальний режим оподаткування. Використання цих важелів сприяє збалансованому природокористуванню, а також реалізації стратегічних напрямів інституціонального забезпечення, як актуальних у вказаному регіоні. Такими є:

- формування розвиненого ринку екологічних послуг;

- законодавчо-нормативне стимулювання щодо розв'язання екологічних проблем;

- розширення співробітництва з міжнародними екологічними організаціями, європейськими країнами;

- розгортання робіт щодо створення системи екологічного моніторингу;

- розробка транскордонних екологічних програм, у яких сторони мають спільну зацікавленість;

- створення спільних природно-заповідних територій.

\section{СПИСОК ВИКОРИСТАНИХ ДЖЕРЕЛ}

1. Гадзало А.Я. Особливості еколого-економічних систем транскордонного співробітництва Карпатського регіону. Науковий вісник НЛту України. Серія: економічна. 2017. Вип. 27 (2). С. $108-112$.

2. Фурдичко O.I. «Екологічні основи збалансованого розвитку агросфери в контексті європейської інтеграції України»: монографрія. К.: ДІА, 2014. 432 с.

3. Постанова Кабінету Міністрів України «Про створення транскордонного біосферного резервату «Західне Полісся»» № 621 від 11.07.2012. [Електронний ресурс]. Режим доступу: http://zakon2.rada. gov.ua/laws/show/998_534

4. Головач Ю.В. Карпатський єврорегіон як форма транскордонного співпрбітництва України з країнами СС. 2010. [Електронний ресурс]. Режим доступу: http://www.rusnauka.com/15_AHSN_2010/ economics/67853.doc/htm

5. Дребот О.I., Гадзало А.Я. Елементи економічного механізму збалансованого природокористування. Economic development strategyin terms of European integration. International scientific-practical conference. May 27, 2016. P. 223-225.

6. Сучасна регіональна політика і транскордонне співробітництво; за наук. ред. В.І. Пили. Хмельницький: Хмельницький університет управління та права, 2006. 412 с.

7. Альберт Гор. Землі у рівновазі. Екологія і людський дух. ВГО «Україна. Порядок денний на ХХІ століття» та Інститут сталого розвитку. Київ: Інтелсфера, 2001. 404 с.

8. ФАО. Офіційний веб-сайт: Офіційний веб-сайт ФАО. [Електронний ресурс]. Режим доступу: http:// www.fao.org/faostat/en/\#data/QC

9. Філеп Д. Еколого-економічні засади розвитку прикордонних регіонів України та Угорщини: автореф. дис. на здобуття наук. ступеня канд. екон. наук: 08.10.01 / Філеп Дюла. Львів, 2003. 18 с.

10. Долішній М., Кравців В. Карпатський регіон у контексті державної економічної політики: оцінка стану і стратегія розвитку. Економіка України. 1995. № 8. С. 24-35.

11. Долішній М. Регіональна соціально-економічна політика. Регіональна економіка. 1997. № 2. С. $16-27$.

12. Долішній М., Демченко В., Мікула Н. Концептуальні підходи до створення польсько-українського єврорегіону «Сян» на основі узагальнення досвіду єврорегіонів на західному кордоні Польщі. Регіональна економіка. 2003. № 1. С. 69-82.

13. Гобела В.В. Огляд економічних, соціальних та екологічних загроз Карпатському регіону. Науковий вісник НЛТУ України. 2010. Вип. 20.13. С. 81-87.

14. Манів 3.О., Луцький I.М., Манів С.З. Регіональна економіка. Львів: Магнолія, 2006. 638 с.

15. Зюлковскі М. Польсько-українські взаємини як складова архітектури сучасної Європи. Віче. 2008. № 6. C. $72-74$.

16. Про основні засади (стратегію) державної екологічної політики України на період до 2020 року: Закон України від 21 грудня 2010 р. № 2818-VI. Відомості Верховної Ради України. 2011. № 26. Ст. 218. [Електронний ресурс]. Режим доступу: https://zakon.rada.gov.ua/laws/show/2818-17

\section{Інформація про автора}

Гадзало Андрій Ярославович - кандидат економічних наук, науковий співробітник лабораторії екологічного менеджменту, Інститут агроекології і природокористування Національної академії аграрних наук України (Україна, 03143, м. Київ, вул. Метрологічна, e-mail: ahadzalo@ukr.net). 
A.Ya Gadzalo

$\mathrm{PhD}$ in Economics

Institute of Agroecology and Nature Management of NAAS

(Ukraine, Kyiv; e-mail: ahadzalo@ukr.net)

\section{CONCEPTUAL FOUNDATIONS OF THE INSTITUTIONAL SUPPORT OF THE ECOLOGICAL AND ECONOMIC CONDITION OF THE CARPATHIAN REGION}

The article describes the current state of socio-economic and environmental indicators and features of the development of the Carpathian region as a border region. The main industries of the Carpathian region are identified. It is proved that the effective functioning of the system of regulation of sustainable development of the Carpathian region is determined by the strategic priorities of the state, as well as by the programmatic approach to the implementation of regulatory actions through the system of methods and tools that the state has in implementing environmental policy in trans boundary territories. In fact, the identified strategic priorities, which are outlined in the cross-border cooperation programming documents for the development of the regions, are in most cases declarative. The regularity of the development of regulation of the sustainable development of the Carpathian region in the context of environmental security has been revealed, which is to strengthen the role of the environmental factor in the border regions. It is determined that differences of cross-border regions on both sides of the border in ecological and economic aspects determine the peculiarities of functioning of systems of organization, management and regulation of cross-border cooperation at the national level. Conceptual ideas on institutional support of balanced nature management, elements and directions of their interaction are offered. It has also been proven that through the use of economic levers, they ensure a balanced use of nature and the use of strategic directions for the implementation of institutional support, since these directions are becoming relevant in the border region today.

Keywords: institutional support, cross-border cooperation, border regions, ecological and economic principles, gross regional product, capital investment, level of profitability.

\section{REFERENCES}

1. Gadzalo, A.Ya. (2017). Osoblyvosti ekologo-ekonomichnyh system transkordonnogo spivrobitnyctva Karpats'kogo region [Features of ecological and economic systems of transboundary cooperation of the Carpathian region]. Naukovyj visnyk NLTU Ukrai'ny. Serija: ekonomichna [Scientific Bulletin of NLTU of Ukraine. Series: economic], 27(2). 108-112. (In Ukr.)

2. Furdychko, O.I. (2014). Ekologichni osnovy zbalansovanogo rozvytku agrosfery $v$ konteksti jevropejs'koi' integracii' Ukrai'ny [Ecological bases of balanced development of the agrosphere in the context of European integration of Ukraine]. Kyiv. DIA, 432. (In Ukr.)

3. The Verkhovna Rada of Ukraine (2012). Resolution of the Cabinet of Ministers of Ukraine «On creation of the transboundary biosphere reserve «Western Polesie»» Retrieved from: http://zakon2.rada.gov. ua/laws/show/998_534 (date of accesse: 19.05.2019).

4. Holovach, YU.V. (2010). Karpatskyi yevrorehion yak forma transkordonnoho spivprbitnytstva Ukrainy z krainamy YeS [Carpathian Euroregion as a form of cross-border cooperation between Ukraine and EU countries]. [Electronic source]. URL: http://www.rusnauka.com/15_AHSN_2010/economics/67853. doc/htm (In Ukr.)

5. Drebot, O.I. \& Gadzalo, A.YA. (2016). Elementy ekonomichnogo mehanizmu zbalansovanogo pryrodokorystuvannja [Elements of the economic mechanism of balanced nature management]. Economic development strategyin terms of European integration. - international scientific-practical conference. May 27, 223-225. (In Ukr.)

6. Pyly, V.I. (2006). Suchasna regional'na polityka i transkordonne spivrobitnyctvo [Contemporary Regional Policy and Cross-Border Cooperation]. Khmelnytskyi: Khmelnytsky University of Management and Law. 412. (In Ukr.).

7. Al'bert, H. (2001). Zemli u rivnovazi. Ekologija i ljuds'kyj duh [Earth in equilibrium. Ecology and the human spirit]. Kyiv: Intelsfera. 404. (In Ukr.)

8. The official site of the FAO. [Electronic source]. URL: http://www.fao.org/faostat/en/\#data/QC

9. Filep, D. (2003). Ekologo-ekonomichni zasady rozvytku prykordonnyh regioniv Ukrai'ny ta Ugorshhyny [Ecological and economic principles of development of the border regions of Ukraine and Hungary]: author's abstract. Dis. ... Cand. Econ. Sciences: 08.10.01 / Lviv, 2003. 18. (In Ukr.).

10. Dolishniy, M. \& Kravtsiv, V. (1995). Karpats'kyj region u konteksti derzhavnoi' ekonomichnoi' polityky: ocinka stanu i strategija rozvytku [Carpathian region in the context of state economic policy: state assessment and development strategy]. Ekonomika Ukrai'ny [Ukraine economy], 8. 24-35. (In Ukr.)

11. Dolishniy, M. (1997). Regional'na social'no-ekonomichna polityka [Regional socio-economic policy]. Regional'na ekonomika [Regional economy], 2. 16-27. (In Ukr.) 
12. Dolishniy, M., Demchenko, V. and Mikula, N (2003). Konceptual'ni pidhody do stvorennja pol's'ko-ukrai'ns'kogo jevroregionu «Sjan» na osnovi uzagal'nennja dosvidu jevroregioniv na zahidnomu kordoni Pol'shhi [Conceptual approaches to the creation of the Polish-Ukrainian Euroregion «Syan» based on the generalization of the experience of the Euroregions on the western border of Poland]. Regional'na ekonomika [Regional economy], 1. 69-82. (In Ukr.)

13. Gobela, V.V. (2010). Ogljad ekonomichnyh, social'nyh ta ekologichnyh zagroz Karpats'komu region [Review of economic, social and environmental threats to the Carpathian region]. Naukovyj visnyk NLTU Ukrai'ny [Scientific Bulletin of NLTU of Ukraine], 20.13. 81-87. (In Ukr.)

14. Maniv, Z.O., Luts'kyy, I.M. and Maniv, S.Z. (2006). Regional'na ekonomika [Regional economy]. Lviv: Magnolija. 638. (In Ukr.)

15. Zyulkovski, M. (2008). Polish-Ukrainian relations as a component of modern European architecture [Pol's'ko-ukrai'ns'ki vzajemyny jak skladova arhitektury suchasnoi' Jevropy]. Viche [Viche], 6. 72-74. (In Ukr.)

16. The Verkhovna Rada of Ukraine (2010), The Law of Ukraine «On the Fundamental Principles (Strategy) of the State Environmental Policy of Ukraine for the Period up to 2020», Retrieved from: https: //zakon. rada.gov.ua/laws/show/2818-17 (date of accesse: 22.04.2019).

\section{Author}

Gadzalo Andriy Yaroslavovich - PhD in Economics, Researcher at the environmental management laboratory, Institute of Agroecology and Nature Management of NAAS (Ukraine, 03143, Kyiv, 12 Metrologichna St.; e-mail: ahadzalo@ukr.net).

\section{HOBETH}

\section{ЗАНЕПАД ПРИРОДИ ВНАСЛІДОК ЛЮДСЬКОЇ ДІЯЛЬНОСТІ ТА ЗМІН КЛІМАТУ}

Міжурядова науково-політична платформа з біорізноманіття та екосистем, заснована під егідою ООН, опублікувала доповідь, у якій йдеться про безпрецедентний занепад природи внаслідок людської діяльності та змін клімату. Про це розповів на брифінгу речник генсека ООН Стефан Дюжаррік, повідомляє Укрінформ.

Нинішня доповідь стала першим таким документом з 2005 року, і нині являє собою найповнішу оцінку стану біорізноманіття в історії досліджень. Речник генсека ООН додав, що документ виділяє п'ять основних чинників негативних природних змін. Найгірше на довкіллі позначаються зміни у наземному та морському природокористуванні, далі йде пряма експлуатація організмів, зміни клімату, забруднення повітря та інвазійні чужорідні види.

Щороку у світі видобувається близько 60 мільярдів тонн відновлюваних та невідновлюваних природних ресурсів — це вдвічі більше, ніж у 1980 році. Загалом під загрозою зникнення перебуває до 1 мільйона біологічних видів, багато з них - уже протягом наступних десяти років. Нині на Землі близько 8 млн видів, з них 5,5 млн - комахи. Вимирання також загрожує 40\% видів амфрібій, 33\% коралів, більш ніж третині всіх морських ссавців. На цьому тлі середнє підвищення рівня океанів за останні два десятиріччя становить більше 3 мм за рік. Викиди, які спричиняють парниковий ефект виросли на 100\% з 1980 року, спричинивши підвищення глобальної температури щонайменше на $0,7^{\circ} \mathrm{C}$, констатується в доповіді. 